\title{
Spectroscopic and Biological Studies on Newly Synthesized Cobalt (II) and Nickel (II) Complexes with 2-Acetyl Coumarone Semicarbazone and 2-Acetyl Coumarone Thiosemicarbazone
}

\author{
Sanjay Goel, ${ }^{1}$ Sulekh Chandra, ${ }^{2}$ and Sudhanshu Dhar Dwivedi ${ }^{1}$ \\ ${ }^{1}$ Department of Chemistry, Government Science \& Commerce College, M.P. Bhoj (open) University, Benazeer, Bhopal 462016, India \\ ${ }^{2}$ Department of Chemistry, Zakir Husain Delhi College, University of Delhi, Jawaharlal Nehru Marg, New Delhi 110002, India
}

Correspondence should be addressed to Sulekh Chandra; schandra_00@yahoo.com

Received 13 June 2012; Accepted 1 October 2012

Academic Editor: Filomena Conforti

Copyright ( $\odot 2013$ Sanjay Goel et al. This is an open access article distributed under the Creative Commons Attribution License, which permits unrestricted use, distribution, and reproduction in any medium, provided the original work is properly cited.

$\mathrm{Co}(\mathrm{II})$ and $\mathrm{Ni}(\mathrm{II})$ complexes of general composition $\mathrm{ML}_{2} \mathrm{X}_{2}\left(\mathrm{M}=\mathrm{Co}(\mathrm{II}), \mathrm{Ni}(\mathrm{II}) ; \mathrm{X}=\mathrm{Cl}^{-}, \mathrm{NO}_{3}{ }^{-}\right)$were synthesized by the condensation of metal salts with semicarbazone/thiosemicarbazone derived from 2-acetyl coumarone. The ligands and metal complexes were characterized by NMR, elemental analysis, molar conductance, magnetic susceptibility measurements, IR, and atomic absorption spectral studies. On the basis of electronic, molar conductance and infrared spectral studies, the complexes were found to have square planar geometry. The Schiff bases and their metal complexes were tested for their antibacterial and antioxidant activities.

\section{Introduction}

Research on the coordination chemistry, analytical applications, and biological activities of Schiff base complexes has increased steadily for many years. A large number of Schiff bases and their complexes have been studied for their interesting and important biological properties, for example, antimicrobial (El-Wahab et al. [1]), antiviral (Kolocouris et al. [2]), antifungal (Rodríguez-Argüelles et al. [3]), antitumour (Ainscough et al. [4]), and other biological activities (Bharamagouclar et al. [5]; Zhu et al. [6]; Shalin et al. [7]; Kothari and Sharma [8]) particularly with first row of transition metal complexes. The formation of variety of metal complexes with Schiff base ligands as mentioned in our earlier studies (Chandra and Kumar [9]; Chandra and Kumar [10]; Chandra and Gupta [11]) indicates the spectacular progress in coordination and bioinorganic chemistry. It has been demonstrated through several studies that the biological activity of Schiff's bases is enhanced on chelation with a metal ion (Sengupta et al. [12]). In the view of the facts that the metal complexes are better therapeutic agents (Chandra et al. [13]; Kumar and Chandra [14]) as compared to the Schiff bases, the aim of this study is to synthesize the new class of metal complexes with newly synthesized Schiff base ligands and different metal salts, to find their biological activity such as antioxidant and antibacterial activities and to observe the impact of complexation on their therapeutic values.

\section{Experimental}

All the chemicals used in the present work were of high purity, Anala R grade, and procured from Sigma-Aldrich. Metal salts were purchased from E. Merck and used as received. The solvents used were either spectroscopic pure from SRL/BDH or purified by the recommended methods (Vogel [15]).

2.1. Synthesis of 2-Acetyl Coumarone Semicarbazone (SCL). An aqueous solution of semicarbazide $\mathrm{HCl}(1.11 \mathrm{~g}, 0.01 \mathrm{~mol})$ was added to an ethanolic solution of 2-acetyl coumarone $(1.60 \mathrm{~g}, 0.01 \mathrm{~mol})$ in the presence of sodium acetate $(0.82 \mathrm{~g}$, $0.01 \mathrm{~mol})$. The reaction mixture was stirred vigorously for $2 \mathrm{~h}$. The completion of the reaction was confirmed by the TLC. The yellow product formed was collected by filtration which was washed several times with hot water and dried in vacuum 
TABLE 1: Molar conductance and elemental analysis data.

\begin{tabular}{|c|c|c|c|c|c|c|c|c|c|}
\hline \multirow{2}{*}{ Ligand/complex } & \multirow{2}{*}{$\Lambda_{M}$} & \multirow{2}{*}{ Atomic mass } & \multirow{2}{*}{ Colour } & \multirow{2}{*}{ M.P $\left({ }^{\circ} \mathrm{C}\right)$} & \multirow{2}{*}{ Yield (\%) } & \multicolumn{4}{|c|}{ Elemental analysis data (\%) found (calculated) } \\
\hline & & & & & & M & $\mathrm{C}$ & $\mathrm{H}$ & $\mathrm{N}$ \\
\hline SCL & - & 217 & Yellow & 224 & 72 & - & $59.83(60.82)$ & $4.97(5.10)$ & $19.12(19.34)$ \\
\hline$\left[\mathrm{Co}(\mathrm{SCL})_{2}\right](\mathrm{Cl})_{2}$ & 152 & 563 & Brown & 230 & 72 & $10.42(10.44)$ & $46.92(46.83)$ & $3.97(3.93)$ & $14.92(14.89)$ \\
\hline$\left[\mathrm{Co}(\mathrm{SCL})_{2}\right]\left(\mathrm{NO}_{3}\right)_{2}$ & 184 & 616 & Brown & 219 & 71 & $9.53(9.55)$ & $43.89(42.80)$ & $3.62(3.59)$ & $18.37(18.15)$ \\
\hline$\left[\mathrm{Ni}(\mathrm{SCL})_{2}\right](\mathrm{Cl})_{2}$ & 158 & 564 & Light brown & 226 & 79 & $10.40(10.41)$ & $46.92(46.85)$ & $3.99(3.93)$ & $15.18(14.90)$ \\
\hline$\left[\mathrm{Ni}(\mathrm{SCL})_{2}\right]\left(\mathrm{NO}_{3}\right)_{2}$ & 179 & 617 & Light brown & 218 & 73 & $9.50(9.51)$ & $43.14(42.82)$ & $3.64(3.59)$ & $18.53(18.16)$ \\
\hline TSCL & - & 233 & light yellow & 197 & 70 & - & $56.21(56.63)$ & $4.59(4.75)$ & $17.81(18.01)$ \\
\hline$\left[\mathrm{Co}(\mathrm{TSCL})_{2}\right](\mathrm{Cl})_{2}$ & 168 & 595 & Brown & 205 & 74 & $9.84(9.88)$ & $45.19(44.30)$ & $3.97(3.72)$ & $13.87(14.09)$ \\
\hline$\left[\mathrm{Co}(\mathrm{TSCL})_{2}\right]\left(\mathrm{NO}_{3}\right)_{2}$ & 180 & 648 & Light brown & 210 & 81 & $9.05(9.07)$ & $39.98(40.68)$ & $3.37(3.41)$ & $17.82(17.25)$ \\
\hline$\left[\mathrm{Ni}(\mathrm{TSCL})_{2}\right](\mathrm{Cl})_{2}$ & 174 & 596 & Light yellow & 199 & 71 & $9.84(9.84)$ & $45.15(44.32)$ & $3.86(3.72)$ & $13.89(14.10)$ \\
\hline$\left[\mathrm{Ni}(\mathrm{TSCL})_{2}\right]\left(\mathrm{NO}_{3}\right)_{2}$ & 187 & 649 & Brown & 198 & 78 & $9.02(9.04)$ & $40.16(40.70)$ & $3.84(3.42)$ & $17.54(17.26)$ \\
\hline
\end{tabular}

$\Lambda_{M}$ : molar conductance $\left(\Omega^{-1} \mathrm{~cm}^{2} \mathrm{~mol}^{-1}\right)$.

over $\mathrm{P}_{4} \mathrm{O}_{10}$. The characterization details are tabulated in Table 1. (See Scheme 1.)

2.2. Synthesis of 2-Acetyl Coumarone Thiosemicarbazone (TSCL). Hot ethanolic solution of 2-acetyl coumarone $(1.60 \mathrm{~g}, 0.01 \mathrm{~mol})$ was mixed with hot ethanolic solution of thiosemicarbazide $(0.91 \mathrm{~g}, 0.01 \mathrm{~mol})$ in the presence of 0.5 $\mathrm{mL}$ acetic acid. The contents were refluxed at $70-80^{\circ} \mathrm{C}$ for about 3-4 h. The completion of the reaction was confirmed by the TLC. The solvent was removed using a rotary evaporator and light yellow coloured solid was obtained. It was washed with cold ethanol and dried under vacuum over $\mathrm{P}_{4} \mathrm{O}_{10}$. The characterization details are tabulated in Table 1. (See Scheme 2.)

2.3. Preparation of Metal Complexes. Hot ethanolic solution of metal salts ( $1 \mathrm{mmol})$, for example, nickel chloride hexahydrate $(0.238 \mathrm{~g})$, nickel nitrate hexahydrate $(0.292 \mathrm{~g})$, cobalt chloride hexahydrate $(0.237 \mathrm{~g})$, or cobalt nitrate hexahydrate $(0.291 \mathrm{~g})$, was mixed with hot ethanolic solution of the corresponding ligand $(2 \mathrm{mmol})$, for example, SCL $(0.434 \mathrm{~g})$ or TSCL $(0.466 \mathrm{~g})$. The mixture was refluxed for 4-5 hours at $70-80^{\circ} \mathrm{C}$. On cooling the contents, the complex separated out in each case. It was filtered, washed with $50 \%$ ethanol, and dried under vacuum over $\mathrm{P}_{4} \mathrm{O}_{10}$. The characterization details are tabulated in Table 1.

2.4. Physical Measurements. The $\mathrm{C}, \mathrm{H}$, and $\mathrm{N}$ were analyzed on a Carlo-Erba 1106 elemental analyzer. Metal contents were determined by Atomic Absorption studies. Molar conductance was measured on an ELICO (CM82T) conductivity bridge. Magnetic susceptibilities were measured at room temperature on a Gouy balance using $\mathrm{CuSO}_{4} \cdot 5 \mathrm{H}_{2} \mathrm{O}$ as calibrant. IR spectra $(\mathrm{KBr})$ were recorded on a FTIR spectrum BX-II spectrophotometer. The electronic spectra were recorded in DMSO on a Shimadzu UV mini-1240 spectrophotometer. The ${ }^{1} \mathrm{H}$ NMR spectrums were recorded on a Jeol FT-NMR Spectrometer using DMSO as a solvent. Thermogravimetry (TG) and Differential Thermogravimetric (DTA) analysis for the metal complexes were carried out on a Perkin Elmer
(Diamond) TG-DTA spectrometer for the determination of complex entrapped water.

\section{Results and Discussion}

3.1. Infrared Spectra of SCL. The IR spectrum of ligand SCL (Figure 1) shows bands at 3456 and $3144 \mathrm{~cm}^{-1}$ which may be assigned to $\left[v\left(\mathrm{NH}_{2}\right)\right]$ and $[v(\mathrm{NH})]$ groups, respectively. The bands due to $[v(\mathrm{C}=\mathrm{O})]$ appeared at $1720 \mathrm{~cm}^{-1}$ and the bands at 1562 or $1446 \mathrm{~cm}^{-1}$ may be assigned to symmetric or asymmetric $[v(\mathrm{C}=\mathrm{N})]$ group (Kothari and Sharma [8]; Chandra and Gupta [11]).

3.2. The ${ }^{1} H$ NMR Spectra of SCL. The ${ }^{1} \mathrm{H}$ NMR spectrum of the ligand SCL (Figure 2) was recorded in DMSO. It shows signals at $\delta 2.21 \mathrm{ppm}\left(3 \mathrm{H}, \mathrm{CH}_{3}-\mathrm{C}, \mathrm{s}\right), \delta 6.52 \mathrm{ppm}(2 \mathrm{H}$, $\left.\mathrm{NH}_{2}-\mathrm{CO}, \mathrm{s}\right), \delta 9.62 \mathrm{ppm}(1 \mathrm{H}, \mathrm{N}-\mathrm{NH}-\mathrm{CO}, \mathrm{s}), \delta 7.36 \mathrm{ppm}$ $(1 \mathrm{H}, \mathrm{Ph}-\mathrm{CH}-\mathrm{C}, \mathrm{s}), \delta 7.62(1 \mathrm{H}, \mathrm{Ph}, \mathrm{d}), \delta 7.57 \mathrm{ppm}(1 \mathrm{H}, \mathrm{Ph}$, d), $\delta 7.32(1 \mathrm{H}, \mathrm{Ph}, \mathrm{m})$, and $\delta 7.25 \mathrm{ppm}(1 \mathrm{H}, \mathrm{Ph}, \mathrm{m})$.

3.3. Infrared Spectra of TSCL. The IR spectrum of the ligand TSCL (Figure 3) shows bands at 3310 and $3148 \mathrm{~cm}^{-1}$ which may be assigned to $\left[v\left(\mathrm{NH}_{2}\right)\right]$ and $[v(\mathrm{NH})]$ groups, respectively. The bands due to $[v(\mathrm{C}=\mathrm{S})]$ appeared at $1598 \mathrm{~cm}^{-1}$ and the bands at 1497 or $1257 \mathrm{~cm}^{-1}$ may be assigned to symmetric or asymmetric $[v(\mathrm{C}=\mathrm{N})]$ group (Kothari and Sharma [8]; Chandra and Gupta [11]).

3.4. The ${ }^{1} H$ NMR Spectra of TSCL. The ${ }^{1} \mathrm{H}$ NMR spectrum of the ligand TSCL (Figure 4) was recorded in DMSO. It shows signals at $\delta 2.33 \mathrm{ppm}\left(3 \mathrm{H}, \mathrm{CH}_{3}-\mathrm{C}, \mathrm{s}\right), \delta 7.82 \mathrm{ppm}(2 \mathrm{H}$, $\left.\mathrm{NH}_{2}-\mathrm{CO}, \mathrm{s}\right), \delta 10.51 \mathrm{ppm}(1 \mathrm{H}, \mathrm{N}-\mathrm{NH}-\mathrm{CO}, \mathrm{s}), \delta 7.56 \mathrm{ppm}$ $(1 \mathrm{H}, \mathrm{Ph}-\mathrm{CH}-\mathrm{C}, \mathrm{s}), \delta 7.65(1 \mathrm{H}, \mathrm{Ph}, \mathrm{d}), \delta 7.59 \mathrm{ppm}(1 \mathrm{H}, \mathrm{Ph}$, d), $\delta 7.35(1 \mathrm{H}, \mathrm{Ph}, \mathrm{m})$, and $\delta 7.26 \mathrm{ppm}(1 \mathrm{H}, \mathrm{Ph}, \mathrm{m})$.

3.5. Infrared Spectra of Metal Complexes. The assignments of the significant IR spectral bands of the metal complexes are shown in Figures 5, 6, 7, and 8 which clearly show the shifting of the bands corresponding to $v(-\mathrm{C}=\mathrm{N})$ and $v(-\mathrm{C}=\mathrm{S})$ 


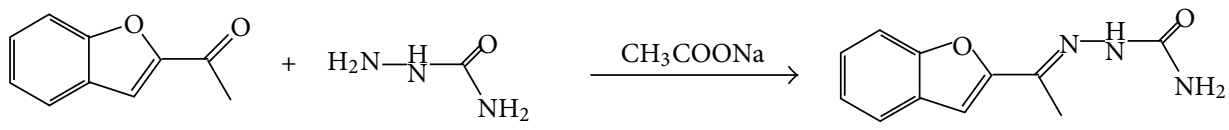

SCHEME 1

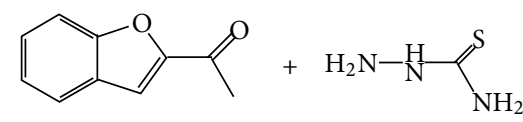<smiles>CC(=O)OCC(N)=S</smiles>

SCHEME 2

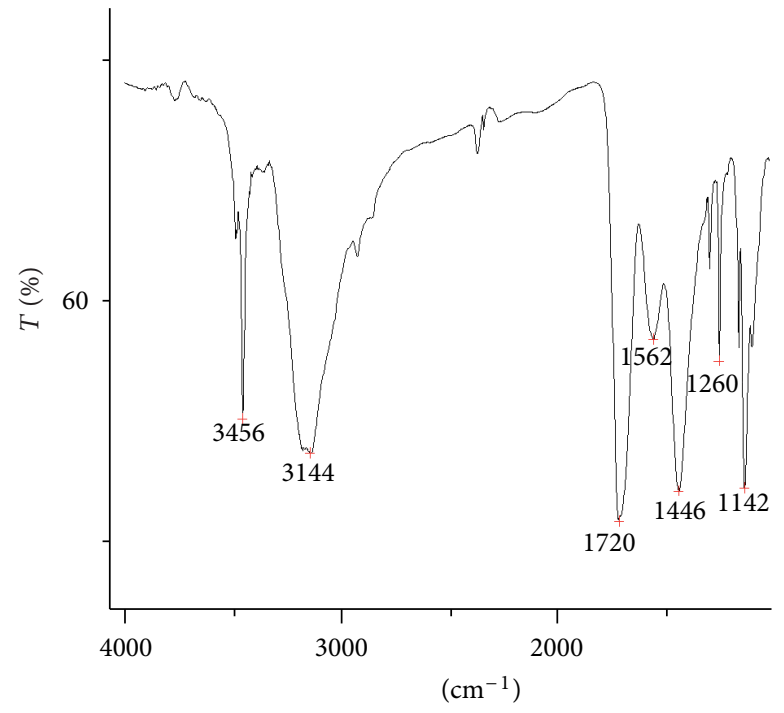

FIGURE 1: IR spectra of SCL.

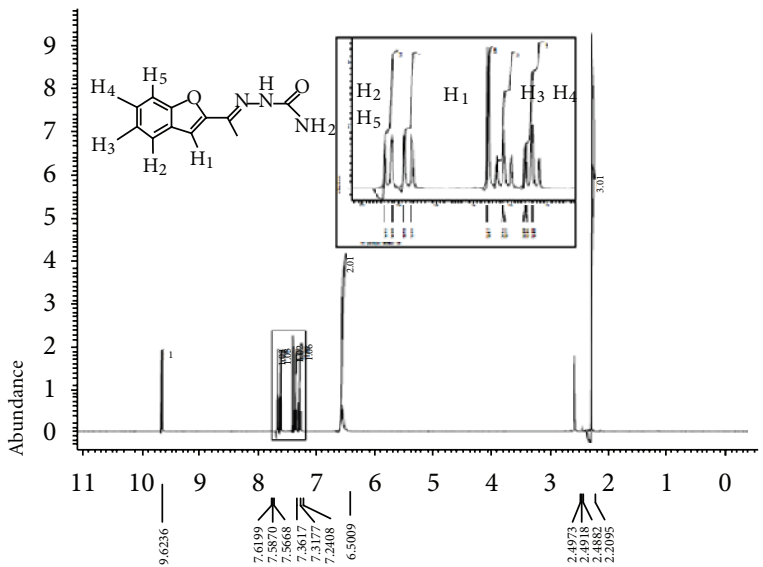

X: parts per million: $1 \mathrm{H}$

FIGURE 2: NMR spectra of SCL.

in thiosemicarbazone or $v(-\mathrm{C}=\mathrm{O})$ in semicarbazone towards the lower side (around ca. $20-50 \mathrm{~cm}^{-1}$ ) on complexation. This suggests that both the ligands act as bidentate chelating agents coordinating through nitrogen of $\mathrm{C}=\mathrm{N}$ group and sulphur

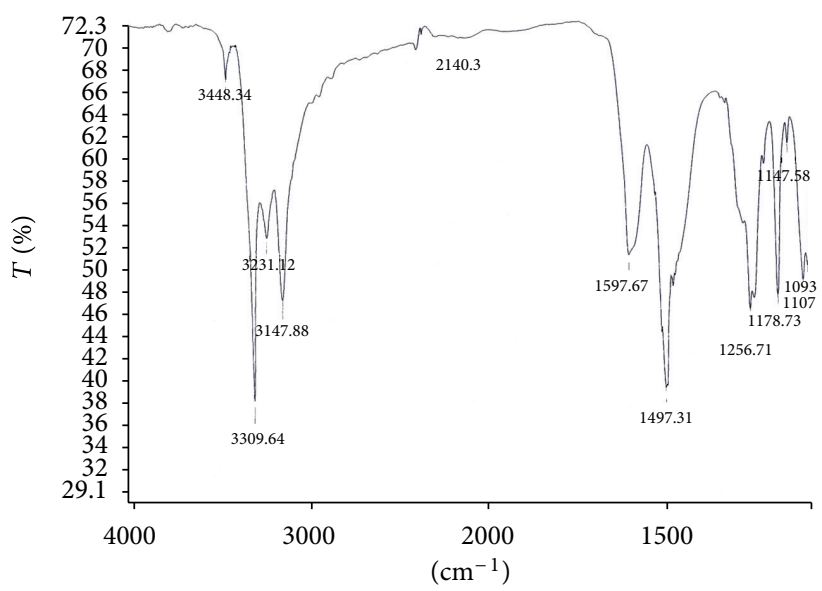

FIgURE 3: IR spectra of TSCL.

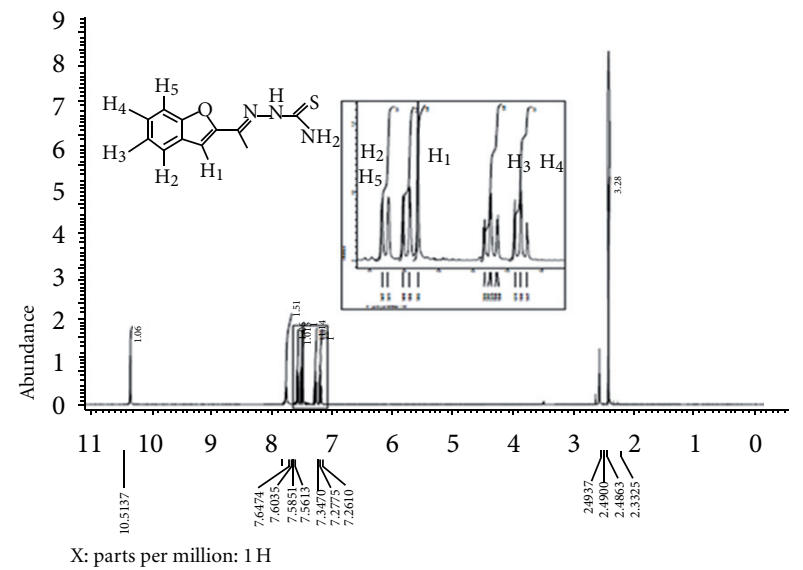

FIGURE 4: NMR spectra of TSCL.

of $\mathrm{C}=\mathrm{S}$ group or oxygen of $\mathrm{C}=\mathrm{O}$ (Kothari and Sharma [8]; Chandra and Gupta [11]).

3.6. The ${ }^{1} \mathrm{H}$ NMR Spectra of Nickel Complexes. The ${ }^{1} \mathrm{H}$ NMR spectra of the nickel complexes were recorded in DMSO. They show shifting of signals corresponding to $\mathrm{CH}_{3}$, $\mathrm{NH}_{2}-\mathrm{CO}$ and $\mathrm{N}-\mathrm{NH}-\mathrm{CO}$ coordination as compared to the ${ }^{1} \mathrm{H}$ NMR spectra of the corresponding ligand. It indicates the 


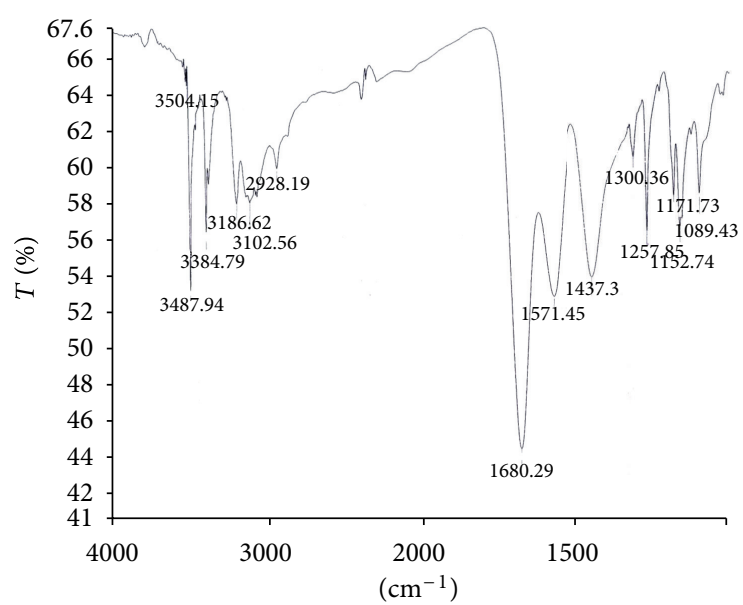

Figure 5: IR spectra of $\left[\mathrm{Co}(\mathrm{SCL})_{2}\right](\mathrm{Cl})_{2}$.

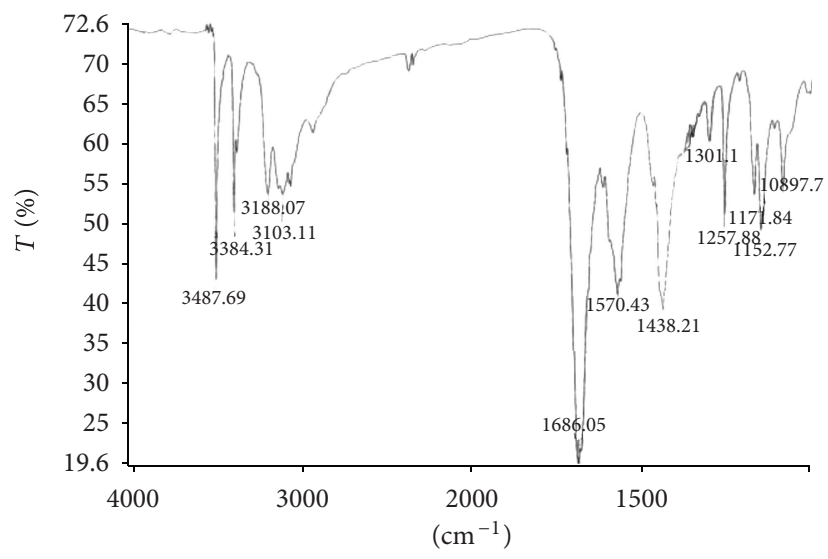

Figure 6: IR spectra of $\left[\mathrm{Ni}(\mathrm{SCL})_{2}\right](\mathrm{Cl})_{2}$.

TABLE 2: Magnetic moment and electronic spectral data of complexes.

\begin{tabular}{|c|c|c|c|}
\hline \multirow{3}{*}{ Complex } & \multirow{3}{*}{$\mu_{\mathrm{eff}}$ (B.M.) } & \multicolumn{2}{|c|}{ Electronic spectral data } \\
\hline & & $v_{1}\left(\mathrm{~cm}^{-1}\right)$ & $v_{2}\left(\mathrm{~cm}^{-1}\right)$ \\
\hline & & \multicolumn{2}{|c|}{$\varepsilon\left(\mathrm{Lmol}^{-1} \mathrm{~cm}^{-1}\right) \varepsilon\left(\mathrm{Lmol}^{-1} \mathrm{~cm}^{-1}\right)$} \\
\hline$\overline{\left[\mathrm{Co}(\mathrm{SCL})_{2}\right](\mathrm{Cl})_{2}}$ & 2.04 & 17267 & 22800 \\
\hline$\left[\mathrm{Co}(\mathrm{SCL})_{2}\right]\left(\mathrm{NO}_{3}\right)_{2}$ & 1.93 & 17648 & 22523 \\
\hline$\left[\mathrm{Ni}(\mathrm{SCL})_{2}\right](\mathrm{Cl})_{2}$ & Diamagnetic & 17856 & 22270 \\
\hline$\left[\mathrm{Ni}(\mathrm{SCL})_{2}\right]\left(\mathrm{NO}_{3}\right)_{2}$ & Diamagnetic & 17245 & 22948 \\
\hline$\left[\mathrm{Co}(\mathrm{TSCL})_{2}\right](\mathrm{Cl})_{2}$ & 2.01 & 17112 & 22842 \\
\hline$\left[\mathrm{Co}(\mathrm{TSCL})_{2}\right]\left(\mathrm{NO}_{3}\right)_{2}$ & 1.85 & 17402 & 22845 \\
\hline$\left[\mathrm{Ni}(\mathrm{TSCL})_{2}\right](\mathrm{Cl})_{2}$ & Diamagnetic & 17813 & 22613 \\
\hline$\left[\mathrm{Ni}(\mathrm{TSCL})_{2}\right]\left(\mathrm{NO}_{3}\right)_{2}$ & Diamagnetic & 17534 & 22400 \\
\hline
\end{tabular}

chelation of the ligand through nitrogen of $\mathrm{C}=\mathrm{N}$ group and sulphur of $\mathrm{C}=\mathrm{S}$ group or oxygen of $\mathrm{C}=\mathrm{O}$.

3.7. Elemental Analysis Data and Molar Conductance of Metal Complexes. The metal contents (Table 1) were determined by the Atomic Absorption studies as shown in Figures 9 and 10. The $\mathrm{C}, \mathrm{H}$, and $\mathrm{N}$ contents in the metal complexes were

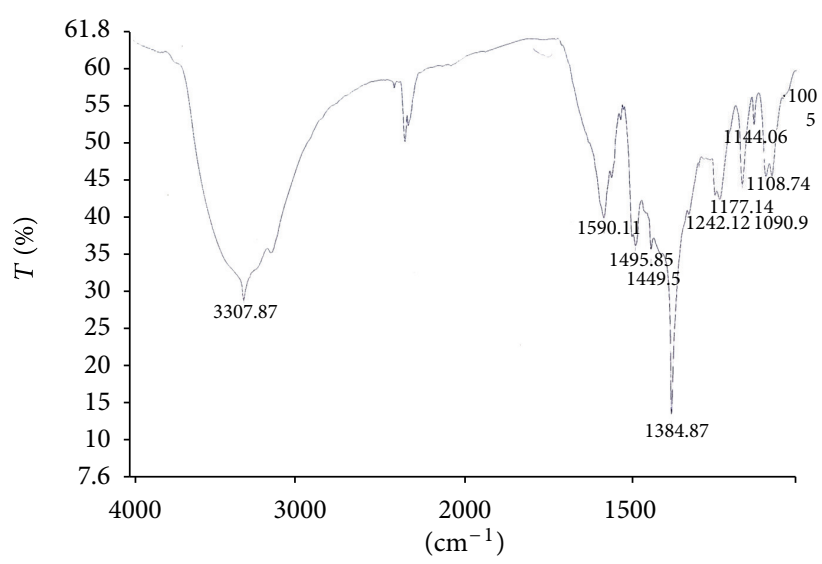

FIGURE 7: IR spectra of $\left[\mathrm{Co}(\mathrm{TSCL})_{2}\right]\left(\mathrm{NO}_{3}\right)_{2}$.

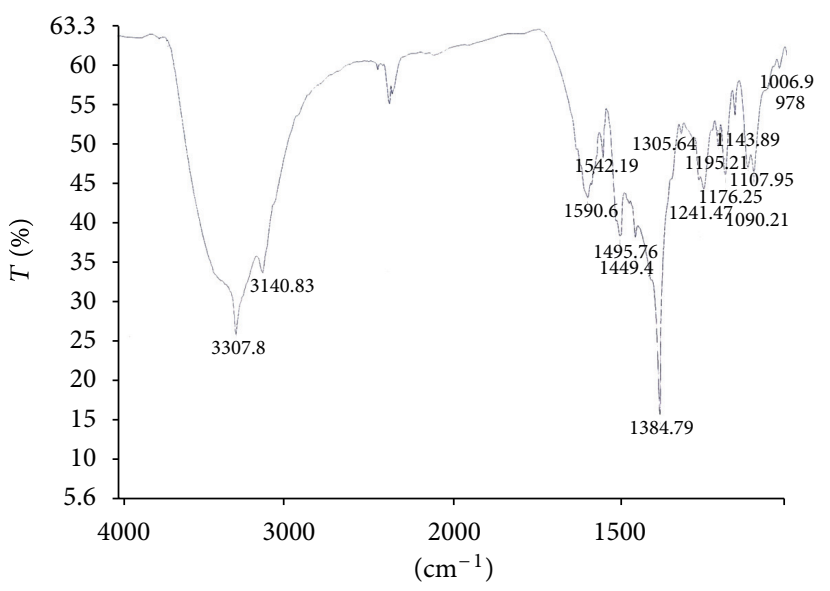

FIGURE 8: IR spectra of $\left[\mathrm{Ni}(\mathrm{TSCL})_{2}\right]\left(\mathrm{NO}_{3}\right)_{2}$.

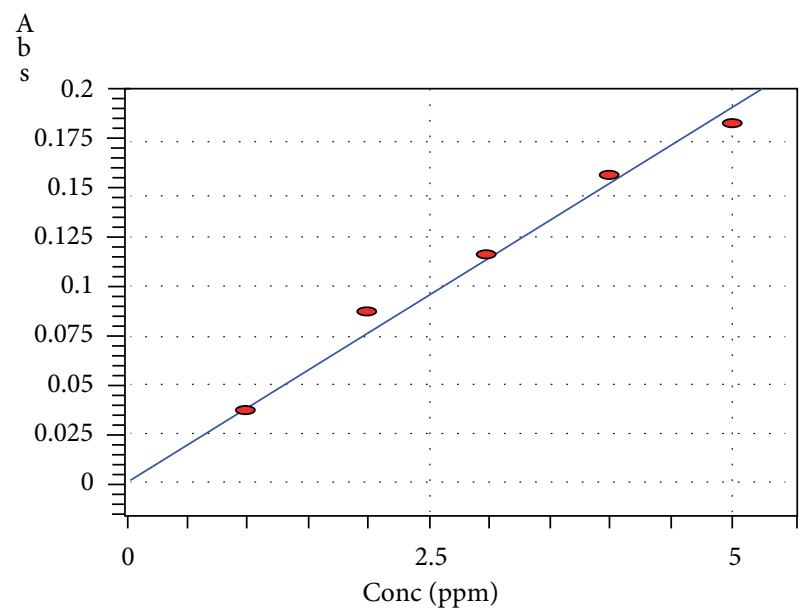

Figure 9: Calibration curve for Co metal complexes for Atomic Absorption studies. The solutions of cobalt complexes (10 ppm), that is, $\left[\mathrm{Co}(\mathrm{SCL})_{2}\right](\mathrm{Cl})_{2},\left[\mathrm{Co}(\mathrm{SCL})_{2}\right]\left(\mathrm{NO}_{3}\right)_{2},\left[\mathrm{Co}(\mathrm{TSCL})_{2}\right](\mathrm{Cl})_{2}$, and, $\left[\mathrm{Co}(\mathrm{TSCL})_{2}\right]\left(\mathrm{NO}_{3}\right)_{2}$, show the absorbance of $0.0396,0.0362$, 0.0374 , and 0.0344 , respectively. $\%$ of Cobalt $=$ Absorbance $\times$ $10 /$ Slope $($ where slope $=0.038$ ). 


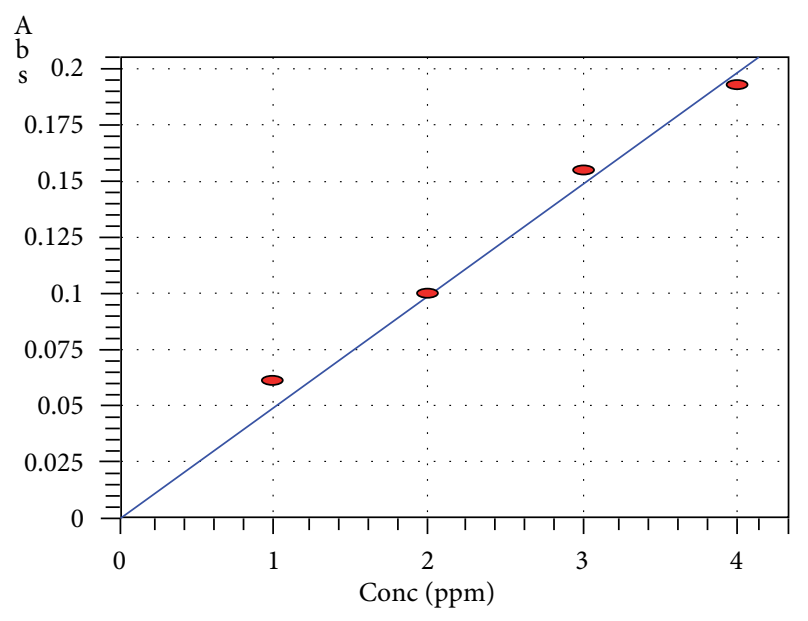

Figure 10: Calibration curve for Ni metal complexes for Atomic Absorption studies. The solutions of nickel complexes (10 ppm), that is, $\left[\mathrm{Ni}(\mathrm{SCL})_{2}\right](\mathrm{Cl})_{2},\left[\mathrm{Ni}(\mathrm{SCL})_{2}\right]\left(\mathrm{NO}_{3}\right)_{2},\left[\mathrm{Ni}(\mathrm{TSCL})_{2}\right](\mathrm{Cl})_{2}$, and $\left[\mathrm{Ni}(\mathrm{TSCL})_{2}\right]\left(\mathrm{NO}_{3}\right)_{2}$, show the absorbance of $0.0520,0.0475,0.0492$, and 0.0451 , respectively. $\%$ of Nickel $=$ Absorbance $\times 10 /$ Slope (where slope $=0.050)$.

TABLE 3: Influence of ligands and metal complexes on the initiation of lipid peroxidation.

\begin{tabular}{lc}
\hline Ligands/complexes & Percent of control \\
\hline SCL & 98 \\
{$\left[\mathrm{Co}(\mathrm{SCL})_{2}\right](\mathrm{Cl})_{2}$} & 82 \\
{$\left[\mathrm{Co}(\mathrm{SCL})_{2}\right]\left(\mathrm{NO}_{3}\right)_{2}$} & 86 \\
{$\left[\mathrm{Ni}(\mathrm{SCL})_{2}\right](\mathrm{Cl})_{2}$} & 72 \\
{$\left[\mathrm{Ni}(\mathrm{SCL})_{2}\right]\left(\mathrm{NO}_{3}\right)_{2}$} & 77 \\
$\mathrm{TSCL}$ & 96 \\
{$\left[\mathrm{Co}(\mathrm{TSCL})_{2}\right](\mathrm{Cl})_{2}$} & 76 \\
{$\left[\mathrm{Co}(\mathrm{TSCL})_{2}\right]\left(\mathrm{NO}_{3}\right)_{2}$} & 79 \\
{$\left[\mathrm{Ni}(\mathrm{TSCL})_{2}\right]\left(\mathrm{Cl}_{2}\right)_{2}$} & 58 \\
{$\left[\mathrm{Ni}(\mathrm{TSCL})_{2}\right]\left(\mathrm{NO}_{3}\right)_{2}$} & 63 \\
\hline
\end{tabular}

analyzed by the Elemental Analyzer and are tabulated in Table 1. The molar conductance measurements (Table 1) of the complexes in DMSO correspond to $1: 2$ electrolytic nature (Shakir et al. [16]). On the basis of elemental analysis data and molar conductance of the complexes, the metal complexes may be formulated as $\left[\mathrm{ML}_{2}\right] \mathrm{X}_{2}$ (where $\mathrm{M}=\mathrm{Co}(\mathrm{II}), \mathrm{Ni}(\mathrm{II}) ; \mathrm{X}$ $=\mathrm{Cl}^{-}, \mathrm{NO}_{3}{ }^{-}$).

3.8. Magnetic Moment and Electronic Spectral Data of Metal Complexes. At room temperature $\mathrm{Ni}(\mathrm{II})$ complexes show diamagnetic character and $\mathrm{Co}(\mathrm{II})$ complexes show magnetic moment in the range 1.85-2.04 B.M. (Table 2) corresponding to one unpaired electron. These values correspond to low spin configurations of the metal complexes. The electronic spectrum of chloride and nitrate complexes shows electronic spectral bands in the range $17100-17900 \mathrm{~cm}^{-1}$ and
22400-22800 $\mathrm{cm}^{-1}$ corresponding to the following transitions: $v_{1}:{ }^{2} \mathrm{~B}_{1 \mathrm{~g}} \rightarrow{ }^{2} \mathrm{~A}_{1 \mathrm{~g}}, v_{2}:{ }^{2} \mathrm{~B}_{1 \mathrm{~g}} \rightarrow{ }^{2} \mathrm{E}_{\mathrm{g}}$ which indicates the square planar geometry of the complexes.

3.9. TG-DTA Data of Metal Complexes. All the metal complexes show major weight loss above $175^{\circ} \mathrm{C}$ which shows that they are free of any entrapped water. The peaks due to melting of complexes in TG-DTA curve agree well with the melting point of the complexes as determined by the MP apparatus (Make: BUCHI, Model: M-560).

\section{Antioxidant Activity}

4.1. Assay of Initiation of Lipid Peroxidation. The details of the assay procedure are described in the earlier communication (Raj et al. [17]). The reaction mixture in a final volume of $2 \mathrm{~mL}$ consisted of $0.025 \mathrm{M}$ Tris-HCI ( $\mathrm{pH} 7.5$ ), microsomes (1 mg protein) which were taken from the laboratory of Prof. H. G. Raj, Department of Biochemistry, VP Chest Institute and were prepared by adopting the method of Ernster and Nordenbrand [18] (protein was assayed by the method of Lowry et al. [19]), $3 \mathrm{mM}$ ADP, and $0.15 \mathrm{mM}$ $\mathrm{FeCl}_{3}$. The tubes were preincubated for $10 \mathrm{~min}$ at $37^{\circ} \mathrm{C}$ followed by the addition of the test compounds added at a concentration of $100 \mu \mathrm{M}$ in $0.2 \mathrm{~mL}$ of DMSO and then again incubated for $10 \mathrm{~min}$ at $37^{\circ} \mathrm{C}$. The reaction was started by the addition of $0.5 \mathrm{mM} \mathrm{NADPH}$ for initiation of enzymatic lipid peroxidation and incubated for different intervals. The reaction was terminated by the addition of $0.2 \mathrm{~mL}$ of $50 \%$ TCA followed by addition of $0.2 \mathrm{~mL}$ of $5 \mathrm{~N} \mathrm{HCI}$ and $1.6 \mathrm{~mL}$ of $30 \%$ TBA. The tubes were heated in an oil bath at $95^{\circ} \mathrm{C}$ for $30 \mathrm{~min}$, cooled, and centrifuged at $3000 \mathrm{rpm}$. The intensity of the colour of the thiobarbituric acid reactive substance (TBRS) formed was read at $535 \mathrm{~nm}$. The lipid peroxidation was found to be linear up to 15 min under the conditions described here. The results (Table 3 ) illustrate the influence of ligands and metal complexes on the initiation of lipid peroxidation enzymatically. These results clearly indicate that metal complexes have higher antioxidant activities as compared to the schiff's base ligands. Thiosemicarbazone metal complexes show higher antioxidant activities than semicarbazone metal complexes. Moreover, nickel metal complexes show higher antioxidant activities than cobalt metal complexes.

\section{Antibacterial Activity}

The antibacterial activities of the metal complexes were determined at different concentrations $(30 \mu \mathrm{g} / \mathrm{disc})$ against different pathogenic bacteria (Table 4) by using disc diffusion technique and the results were compared with standard antibiotic, Kanamycin $(30 \mu \mathrm{g} /$ disc $)$. It was found that the metal complexes were active against all of the test bacteria but the metal complexes $\left[\mathrm{Co}(\mathrm{TSCL})_{2}\right]\left(\mathrm{NO}_{3}\right)_{2}$ and $\left[\mathrm{Ni}(\mathrm{TSCL})_{2}\right]\left(\mathrm{NO}_{3}\right)_{2}$ were most effective against all pathogenic bacteria as shown in Table 4. The zones of inhibition of the complexes were, however, lesser as compared to standard Kanamycin. The metal complexes have higher antibacterial activities as compared to the Schiff's base 
TABLE 4: Antibacterial activity of ligands and metal complexes.

\begin{tabular}{|c|c|c|c|c|c|c|c|c|c|c|c|}
\hline \multirow{2}{*}{ Test organism } & \multicolumn{11}{|c|}{ Diameter of zones of inhibition (mm) } \\
\hline & $\mathrm{M}_{1}$ & $\mathrm{M}_{2}$ & $\mathrm{M}_{3}$ & $\mathrm{M}_{4}$ & $\mathrm{M}_{5}$ & $\mathrm{M}_{6}$ & $\mathrm{M}_{7}$ & $\mathrm{M}_{8}$ & $\mathrm{~L}_{1}$ & $\mathrm{~L}_{2}$ & Kanamycin \\
\hline Escherichia coli & 8 & 7 & 8 & 7 & 13 & 14 & 12 & 15 & 2 & 2 & 22 \\
\hline Klebsiella species & 6 & 5 & 5 & 4 & 14 & 16 & 14 & 17 & 4 & 5 & 20 \\
\hline Shigella sonnei & 7 & 4 & 6 & 8 & 12 & 15 & 13 & 14 & 3 & 4 & 25 \\
\hline Bacillus subtilis & 9 & 6 & 8 & 5 & 12 & 14 & 14 & 16 & 3 & 3 & 23 \\
\hline
\end{tabular}

$\mathrm{M}_{1}:\left[\mathrm{Co}(\mathrm{SCL})_{2}\right](\mathrm{Cl})_{2} ; \mathrm{M}_{2}:\left[\mathrm{Co}(\mathrm{SCL})_{2}\right]\left(\mathrm{NO}_{3}\right)_{2} ; \mathrm{M}_{3}:\left[\mathrm{Ni}(\mathrm{SCL})_{2}\right](\mathrm{Cl})_{2} ; \mathrm{M}_{4}:\left[\mathrm{Ni}(\mathrm{SCL})_{2}\right]\left(\mathrm{NO}_{3}\right)_{2} ; \mathrm{M}_{5}:\left[\mathrm{Co}(\mathrm{TSCL})_{2}\right](\mathrm{Cl})_{2} ; \mathrm{M}_{6}:\left[\mathrm{Co}(\mathrm{TSCL})_{2}\right]\left(\mathrm{NO}_{3}\right)_{2} ; \mathrm{M}_{7}:$ $\left[\mathrm{Ni}(\mathrm{TSCL})_{2}\right](\mathrm{Cl})_{2} ; \mathrm{M}_{8}:\left[\mathrm{Ni}(\mathrm{TSCL})_{2}\right]\left(\mathrm{NO}_{3}\right)_{2} ; \mathrm{L}_{1}: \mathrm{SCL} ; \mathrm{L}_{2}$ : TSCL.

ligands. Thiosemicarbazone metal complexes show higher activities than semicarbazone metal complexes.

\section{Conclusions}

The present work describes the facile synthesis of metal complexes with newly synthesized Schiff base ligands and their biological activity. On the basis of elemental analysis data, molar conductance, magnetic susceptibility measurements, IR, and atomic absorption spectral studies, the resulting metal complexes may have square planar geometry and may be formulated as $\left[\mathrm{ML}_{2}\right] \mathrm{X}_{2}$ (where $\mathrm{M}=\mathrm{Co}(\mathrm{II}), \mathrm{Ni}(\mathrm{II})$; $\mathrm{X}=$ $\mathrm{Cl}^{-}, \mathrm{NO}_{3}{ }^{-}$). The metal complexes show higher antioxidant and antibacterial activities as compared to the ligands. The nickel complexes derived from 2 -acetyl coumarone thiosemicarbazone show remarkable antioxidant and antibacterial activities.

\section{Acknowledgments}

The authors are thankful to the Principal, Zakir Husain College, Delhi, and the Principal, Government Science \& Commerce College, Benazeer, Bhopal, for providing research facilities.

\section{References}

[1] Z. H. A. El-Wahab, M. M. Mashaly, A. A. Salman, B. A. El-Shetary, and A. A. Faheim, "Co(II), Ce(III) and UO2(VI) bis-salicylatothiosemicarbazide complexes: binary and ternary complexes, thermal studies and antimicrobial activity," Spectrochimica Acta A, vol. 60, no. 12, pp. 2861-2873, 2004.

[2] A. Kolocouris, K. Dimas, C. Pannecouque et al., "New 2-(1adamantylcarbonyl)pyridine and 1-acetyladamantane thiosemicarbazones-thiocarbonohydrazones: cell growth inhibitory, antiviral and antimicrobial activity evaluation," Bioorganic \& Medicinal Chemistry Letters, vol. 12, no. 5, pp. 723-727, 2002.

[3] M. C. Rodríguez-Argüelles, P. Tourón-Touceda, R. Cao et al., "Complexes of 2 -acetyl- $\gamma$-butyrolactone and 2 -furancarbaldehyde thiosemicarbazones: antibacterial and antifungal activity," Journal of Inorganic Biochemistry, vol. 103, no. 1, pp. 35-42, 2009.

[4] E. W. Ainscough, A. M. Brodie, W. A. Denny, G. J. Finlay, and J. D. Ranford, "Nitrogen, sulfur and oxygen donor adducts with copper(II) complexes of antitumor 2-formylpyridinethiosemicarbazone analogs: physicochemical and cytotoxic studies," Journal of Inorganic Biochemistry, vol. 70, no. 3-4, pp. 175-185, 1998.

[5] T. D. Bharamagouclar, M. A. Pujar, and A. R. Alagawadi, "Biological activity of Schiff base and their metal complexes," Current Science, vol. 56, pp. 889-890, 1987.

[6] L. Zhu, N. Chen, H. Li, F. Song, and X. Zhu, "Synthesis, characterization and biological activities of Schiff bases of 2amino-5-mercapto-1,3,4-thiadiazole and their Mo(VI) complexes," Huazhong Shifan Daxue Xuebao Zirankexueban, vol. 37, pp. 499-502, 2003.

[7] K. Shalin, D. N. Dhar, and P. N. Sharma, "Applications of metal complexes of schiff's bases," Journal of Scientific \& Industrial Research, vol. 68, pp. 181-187, 2009.

[8] R. Kothari and B. Sharma, "Synthesis, characterization and in-vitro antimicrobial investigation of some transition metal complexes with the Schiff base of aromatic aldehyde," Journal of Chemistry \& Chemical Sciences, vol. 1, pp. 158-163, 2011.

[9] S. Chandra and U. Kumar, "Spectroscopic characterization of copper(II) complexes of indoxyl N(4)-methyl thiosemicarbazone," Spectrochimica Acta A, vol. 60, no. 12, pp. 2825-2829, 2004.

[10] S. Chandra and A. Kumar, "Spectral and magnetic studies of $\mathrm{Co}(\mathrm{II})$ complexes with some nitrogen-oxygen and nitrogensulphur donor ligands," Journal of Saudi Chemical Society, vol. 11, no. 1, pp. 299-306, 2007.

[11] S. Chandra and L. K. Gupta, "Spectroscopic and biological studies on newly synthesized nickel(II) complexes of semicarbazones and thiosemicarbazones," Spectrochimica Acta A, vol. 62, no. 4-5, pp. 1089-1094, 2005.

[12] S. K. Sengupta, O. P. Pandey, B. K. Srivastava, and V. K. Sharma, "Synthesis, structural and biochemical aspects of titanocene and zirconocene chelates of acetylferrocenyl thiosemicarbazones," Transition Metal Chemistry, vol. 23, no. 4, pp. 349-353, 1998.

[13] S. Chandra, L. K. Gupta, and S. Agrawal, "Synthesis spectroscopic and biological approach in the characterization of novel $\left[\mathrm{N}_{4}\right]$ macrocyclic ligand and its transition metal complexes," Transition Metal Chemistry, vol. 32, no. 5, pp. 558-563, 2007.

[14] U. Kumar and S. Chandra, "Synthesis, spectroscopic characterization of some Schiff base complexes derived from 2methylcyclohexanone and their activity against some fungi," Journal of Saudi Chemical Society, vol. 15, no. 1, pp. 19-24, 2011.

[15] A. I. Vogel, Quantitative Inorganic Analysis Including Elemental Instrumental Analysis, Longmans, London, UK, 2nd edition, 1962. 
[16] M. Shakir, S. P. Varkey, and P. S. Hameed, "Divalent, cobalt, nickel, copper and zinc complexes of tetraaza macrocycles bearing polyamide groups: synthesis and characterization," Polyhedron, vol. 12, no. 23, pp. 2775-2780, 1993.

[17] H. G. Raj, V. S. Parmar, S. C. Jain et al., "Mechanism of biochemical action of substituted 4-methylbenzopyran-2-ones. Part 5: pulse radiolysis studies on the antioxidant action of 7,8-diacetoxy-4-methylcoumarin," Bioorganic and Medicinal Chemistry, vol. 7, no. 9, pp. 2091-2094, 1999.

[18] L. Ernster and K. Nordenbrand, "Assay of initiation of Lipid Peroxidation using thiobarbituric acid reactive substance," Methods in Enzymology, vol. 10, pp. 574-577, 1967.

[19] O. H. Lowry, N. J. Rosebrough, A. L. Farr, and R. J. Randall, "Protein measurement with the Folin phenol reagent," The Journal of Biological Chemistry, vol. 193, no. 1, pp. 265-275, 1951. 

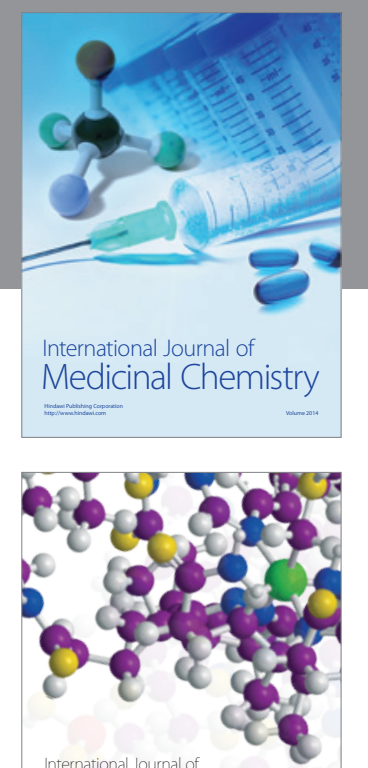

\section{Carbohydrate} Chemistry

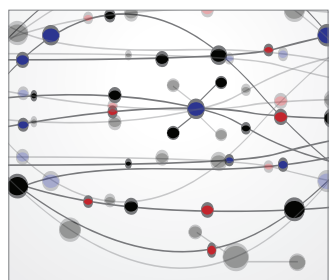

The Scientific World Journal
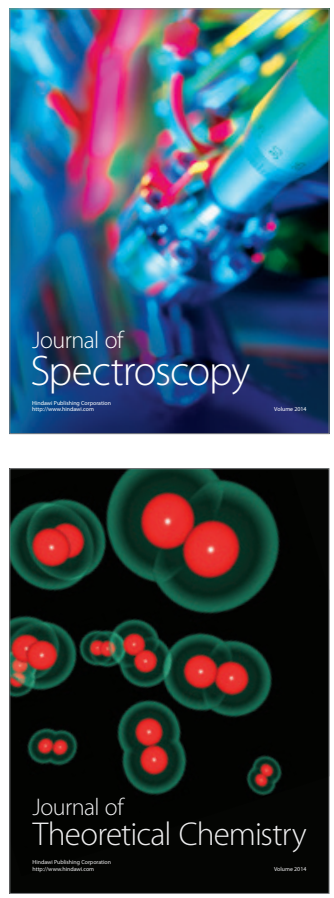
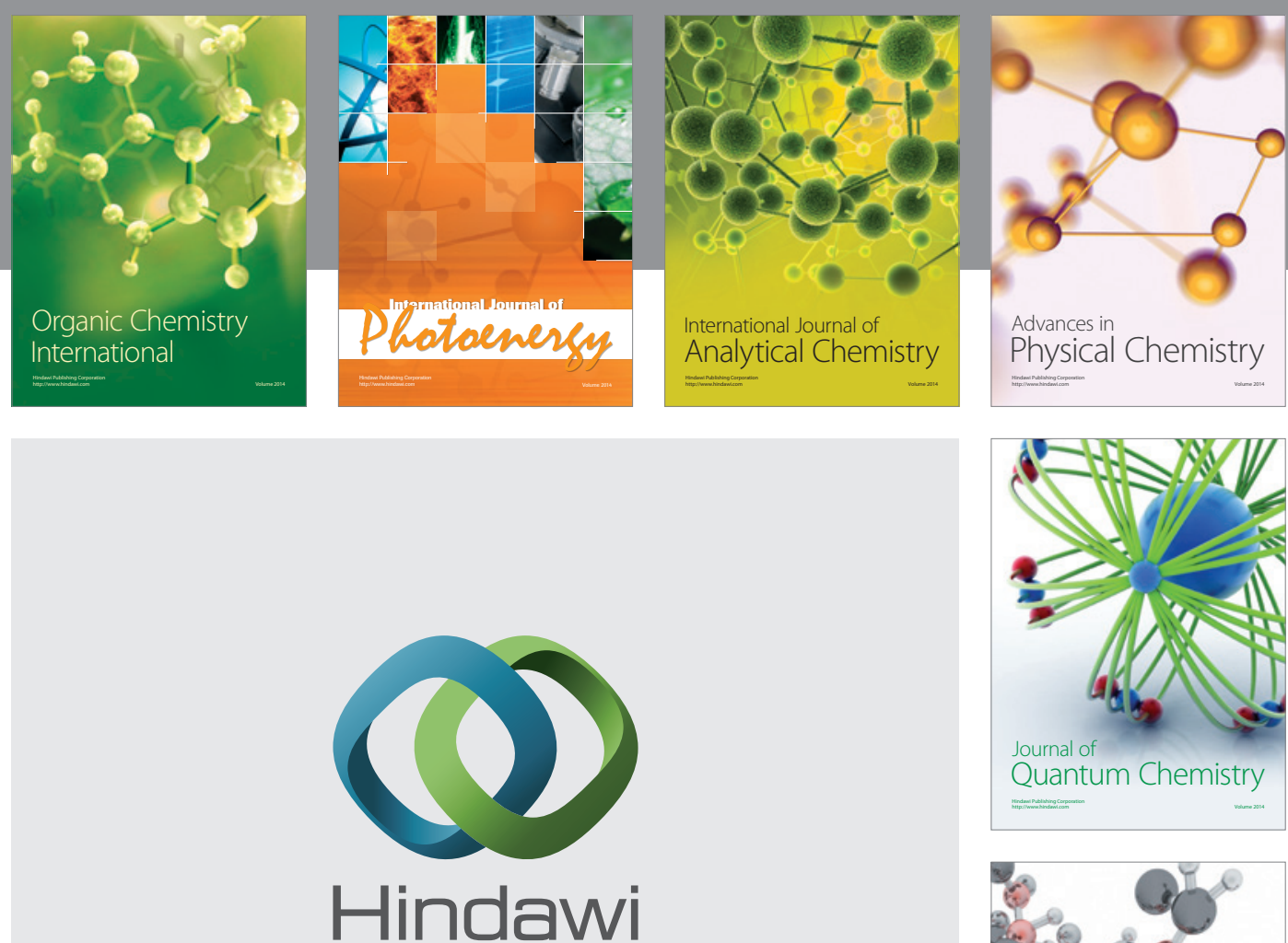

Submit your manuscripts at

http://www.hindawi.com

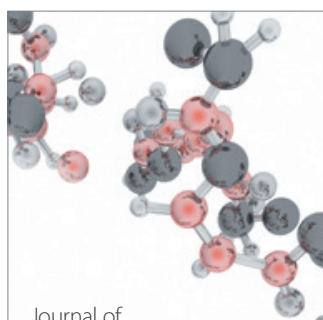

Analytical Methods

in Chemistry

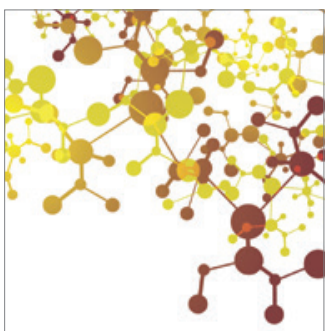

Journal of

Applied Chemistry

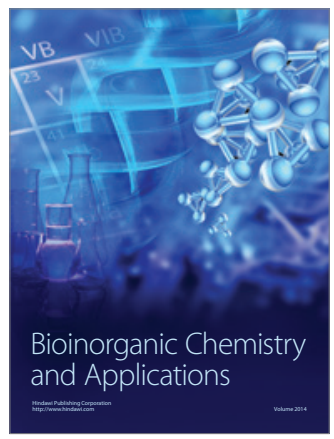

Inorganic Chemistry
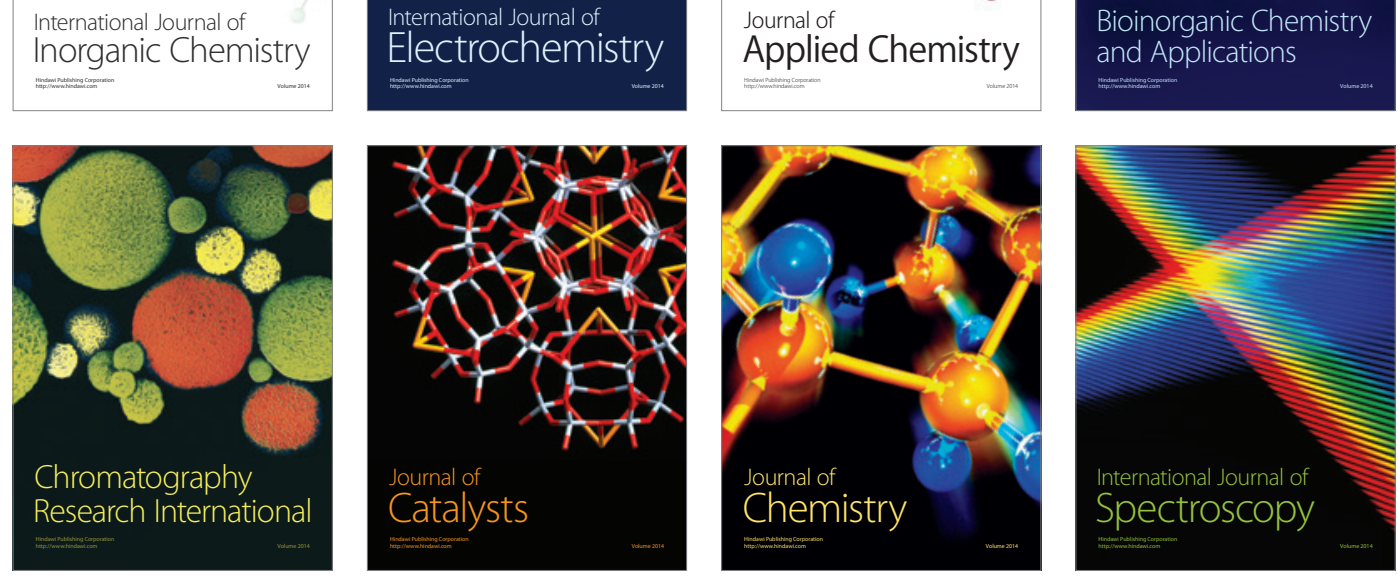